\title{
Comparison of two different proximal femoral nails in instabil intertrochanteric fractures concerning radiological parameters
}

\author{
Gökhan Bülent Sever, M.D.,' ${ }^{1}$ Mehmet Cenk Cankuş, M.D., ${ }^{1}$ () Burçin Karslı, M.D. ${ }^{2}$
}

\begin{abstract}
1'Department of Orthopaedics and Traumatology, Sanko University Faculty of Medicine, Gaziantep-Turkey
${ }^{2}$ Department of Orthopaedics and Traumatology, Gaziantep University Faculty of Medicine, Gaziantep-Turkey
\end{abstract}

\begin{abstract}
BACKGROUND: The aim of this study was to compare two different nail types (i.e., Intertan (IT) and Talon Distal Fix Nail / Lag Screw (TDFN)) used in the treatment of unstable intertrochanteric fractures in mobile patients over 65 years of age in terms of radiological parameters.
\end{abstract}

METHODS: Between June 2013 and August 2018, 106 patients over 65 years old who were operated with closed reduction and internal fixation for intertrochanteric fractures were included in this single-center study. Patients were divided into two groups based on the proximal femoral nail used: IT group and TDFN group. These two groups were compared in terms of age, sex, complication rates and radiological parameters (i.e., reduction quality, tip apex distance (TAD), Parker index, union time, cut-out rate, and varus collapse).

RESULTS: There were no differences between the groups in terms of age, sex, fracture union time as well as reduction quality measured on the first postoperative radiograph, Parker index, and collodiaphysial angle. In the first postoperative radiographs, TAD was higher than $25 \mathrm{~mm}$ in 12 patients in the IT group and in 5 patients in the TDFN group. Although the number of patients with high TAD was more than that of the IT group, varus collapse and the cut-out complications were higher in TDFN nail. In the IT group, nail-dependent complications emerged in 4 patients (trochanter major fracture in 3 cases, femoral fracture in distal screw in $\mathrm{I}$ case) while there was no complication in the TDFN group.

CONCLUSION: Intertan nail is superior to TDFN in preventing varus collapse and the cut-out complications as well as in maintaining of radiological parameters until fracture union. On the other hand, the higher complication rate is a disadvantage of this nail.

Keywords: Comparison; intertrochanteric femur fracture; proximal femoral nail; radiological parameters.

\section{INTRODUCTION}

Intertrochanteric femoral fractures are one of the most common lower extremity fractures among elderly patients who experience it following a minor trauma as a result of osteoporosis. ${ }^{[1]}$ The main aims of the treatment of intertrochanteric fractures in elderly patients are to provide early mobilization and early loading of the bone without complications. [2] Proximal femoral nail (PFN) is mostly used in such fracture treatment for elderly patients due to its minimally invasive application, providing stable fixation and allowing early loading thanks to its design. ${ }^{[3,4]}$ There are various types of PFN designs which include a single, double lag screw, an integrated or lockable lag screw, a single helical blade, and locked design with a nail distal locking screw or self-opening blades. ${ }^{[5]}$

The success of proximal femoral nailing in intertrochanteric fractures is firstly evaluated by radiological parameters, including the reduction quality, collodiaphysial angle, tip apex distance (TAD) and Parker's ratio. Radiological follow-up of

Cite this article as: Sever GB, Cankuş MC, Karslı B. Comparison of two different proximal femoral nails in instabil intertrochanteric fractures concerning radiological parameters. Ulus Travma Acil Cerrahi Derg 2021;27:344-350.

Address for correspondence: Gökhan Bülent Sever, M.D.

Sanko Üniversitesi Tıp Fakültesi Uygulama ve Araştırma Hastanesi, Ortopedi ve Travmatoloji Kliniği, Gaziantep, Turkey

Tel: +90 342 - 21 I 5000 E-mail: gokhanbsever@yahoo.com

Ulus Travma Acil Cerrahi Derg 2021;27(3):344-350 DOI: 10.14744/tjtes.2020.41343 Submitted: 19.11.2019 Accepted: 27.04.2020

Copyright 2021 Turkish Association of Trauma and Emergency Surgery 
the patients is based on such parameters as well as the union state of the fracture. Because of poor bone quality in both femoral neck and intertrochanteric area in elderly patients, establishing lag screw placement in the center-center or low-center position in the surgical technique and creating an appropriate (below $25 \mathrm{~mm}$ ) TAD in the surgical technique are recommended. ${ }^{[6,7]}$

Possible complications, such as the cut-out and varus collapse, can also be related to nail design and nail quality beyond the bone quality of the patient. It has not been established yet whether the nail design contributes to the success of treatment in patients who do not satisfy the optimal radiological parameters (i.e., reduction quality, Parker index, TAD). Accordingly, this study aimed to compare two different proximal femoral nails used in the treatment of intertrochanteric fractures in terms of radiological criteria.

\section{MATERIALS AND METHODS}

One hundred six patients, who were over 65 years old and underwent closed reduction and internal fixation with the diagnosis of intertrochanteric fracture, between June 2013 and August 2018 were included in this single-center retrospective designed study. This study was approved by the University Ethics Committee for Clinical Research Trials (2018/04; 14. 19.04.2018) and was conducted in accordance with the principles in the Declaration of Helsinki. Patients with instable fractures (3 IA2 and A3) according to Arbeitsgemeinschaft für Osteosynthesefragen/Orthopedic Trauma Association (AO/ OTA) classification who were treated with either Talon Distal Fix Nail/Lag Screw (TDFN) (Group I) or Intertan Intertrochanteric Antegrade Nail (IT) (Group 2) nails were included this study. Patients with pathological fractures, bilateral intertrochanteric fractures, immobile pre-fractures or patients treated with other proximal femoral nails, plaque screws or long nails were excluded from this study. Using AO/OTA classification system, all classifications were performed by two surgeons. The minimum follow-up period of the patients was six months. Radiological results and comparisons between the groups were assessed by two senior surgeons on the first postoperative day, on the third and sixth month. Parker index, collodiaphysial angle and TAD were measured on the radiography of the first postoperative day while the reduction quality was evaluated. At third and six months, the radiographs were assessed in terms of determining collodiaphysial angle and cut-out, the possible existence of varus collapse and cut-out. Comparisons between groups were also made at these times with both radiographic parameters and mean fracture union times.

All measurements were based on digital X-rays graphs. Cutout lag screw was defined as approaching the femoral head border from its first placement location by more than I $\mathrm{mm}{ }^{[8]}$ The modified parker ratio was evaluated according to the placement of the lag screw on the anteroposterior radio- graph and lateral plan radiographs. ${ }^{[8,9]}$ If the lag screw had low or centered position on anteroposterior (AP) radiography and it had centered position on lateral radiographs, the modified parker ratio was accepted as reasonable. ${ }^{[8,9]}$ TAD and reduction quality were evaluated as previously described by Baumgaertner et al. ${ }^{[10]}$ Normal or moderate valgus alignment on the anteroposterior radiograph, angulation less than 20 degrees on the lateral radiograph, and displacement criteria of less than $4 \mathrm{~mm}$ were considered to be good reduction. ${ }^{[10,11]}$ On the other hand, the presence of at least one of the criteria above was considered acceptable reduction. ${ }^{[10,11]}$ Collodiaphysial angle was measured between the lines drawn from the center of the femoral neck and from the center of the femoral body. Fracture union was defined as the absence of pain at full load after the formation of callus tissue.

\section{Nail Designs}

\section{Intertan Intertrochanteric Antegrade Nail}

Intertan (IT) nail composed of titanium is a type of nail allowing proximal 4-degree valgus opening. It is a nail with a trapezoidal proximal diameter of $17 \mathrm{~mm}$ and a distal diameter of $10-11.5$ to $13 \mathrm{~mm}$. They have 125 or 130 degrees collodiaphysial angle options. For this nail, two integrated nails are fixed to the femoral neck. The lag screw is $11 \mathrm{~mm}$ and the compression screw is $7 \mathrm{~mm}$ in diameter usually placed $5 \mathrm{~mm}$ shorter than the lag screw. Distal static or dynamic fixation can be achieved with a single screw. Proximal nail system in this nail allows for $15 \mathrm{~mm}$ compression (Fig. Ia).

\section{Talon Distal Fix Nail/Lag Screw (TDFN)}

This nail composed of titanium has a design allowing 4 degrees valgus opening. The diameter of the round proximal nail is $15.5 \mathrm{~mm}$ while the standard distal nail diameter is II $\mathrm{mm}$. The collodiaphysial angle options of 120, I25 and 130 degrees are available. It includes a single lag screw with the diameter of $1 \mathrm{I} \mathrm{mm}$. In this nail design, talons can be opened up to $2 \mathrm{~cm}$ distally from the lag screw. Distal fixation is also achieved statically with the talons. $10 \mathrm{~mm}$ compression can be achieved in the fracture line with this nail (Fig. Ib). (a)

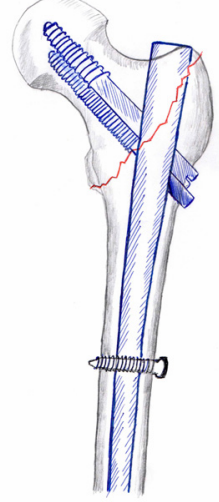

(b)
Figure 1. (a, b) Intertan proximal femoral nail (IT) and Talon Distal Fix Nail/Lag Screw Nail (TDFN). 


\section{Surgical Technique}

All fractures in this single-center retrospective designed study were diagnosed using X-ray. After optimal conditions for anesthesia were provided to the patients, surgery was performed in the first 48 hours following the trauma. The surgical technique used among the patients was similar. Briefly, the patients were operated in lateral decubitus position after anesthesia. With a minimally invasive method, the reduction was visualized with the help of C-arm scopy and entered via trochanter major. Controlling via the scopy and with help of the LAG screw guides, the screws were placed as possible as I/3 caudal on the anteroposterior radiograph, central on the lateral radiographs, and total TAD less than 25 on AP and lateral radiographs. When using the IT nail, the nail diameter was determined by rimmering to the medulla. The compression screw was used to fix the lag screw to the nail. Then, the static locking was achieved with the help of the distal screw. In the TDFN, after the lag screw was placed, the talons in the distal screw and lag screw distal were opened, respectively. After that, the fracture fragments were compressed. The lag screw was fixed to the nail by locking the screw proximal to the nail. Top screw was placed in all cases. On the first postoperative day, the bone was fully loaded with the help of two crutches. A follow-up dressing was performed every three days. On the 15th operative day, all sutures were removed and then the patients were followed-up with monthly radiographs (Fig. 2a-h).

\section{Statistical Method}

Descriptive statistics; mean and standard deviation or median, min-max values for continuous variables specified by measurement; frequency and percentage values are given for qualitative variables. The suitability of continuous data for normal distribution was evaluated by the Kolmogorov-Smirnov test. In group comparisons, for continuous variables, the significance test of the difference between the two means or
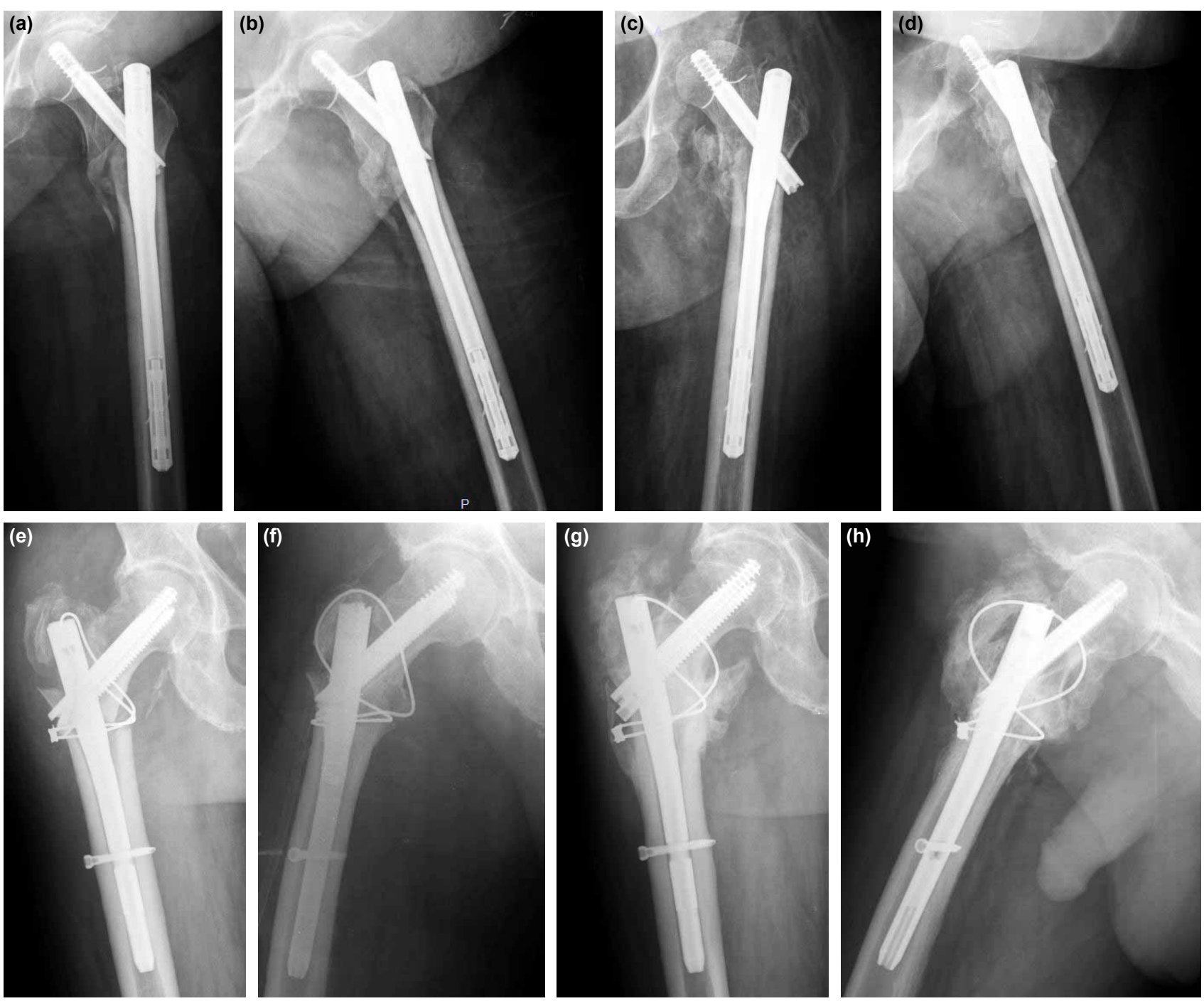

Figure 2. (a, b) Postoperative anteroposterior and lateral hip X-ray of a patient operated on with TDFN. (c, d) Anteroposterior and lateral X-ray of the patient at the $6^{\text {th }}$ postoperative month. $(\mathbf{e}, \mathbf{f})$ Postoperative anteroposterior and lateral hip X-ray of a patient operated on with IT. The trochanter major fracture appears due to nail design. $(\mathbf{g}, \mathbf{h})$ Anteroposterior and lateral X-ray of the patient at the $10^{\text {th }}$ postoperative month. 
Mann-Whitney $U$ test, for the qualitative variables, chi-square test or Fisher's Exact test was used. The difference between the measurements before and after was evaluated by the significance test of the difference between the two peers.

\section{RESULTS}

While group I consisted of 56 patients with TDFN, the second group consisted of 50 patients who underwent IT nailing. In the first group, the mean age was $74.4 \pm 7.7$ (65-90) and the Female/Male ratio was $38 / 18$. Similarly, the mean age was $73.6 \pm 6.2(65-89)$ and the F/M ratio was $36 / 16$ in the second group. There was no statistical difference between these two groups in terms of age and gender ratio. Both groups were also similar concerning fracture classification and all the fractures in both groups were unstable one (Table I). Based on AO/OTA classification, 38 patients had A2 type of fracture, 18 patients had $A 3$ type of fracture in group I. In group 2, 36 patients had $A 2$ type of fracture while 16 patients had A3 type of fracture. No statistically significant difference was found between the two groups concerning fracture classification. The mean duration of fracture union was 13.28 1.3 (II-16) weeks in the group I, while it was $13.14 \pm 1.37$ (II-16) weeks in the group 2 . There was no statistical difference between these two groups concerning mean duration time of fracture union/healing (Table I).

\section{Reduction Quality}

Comparison of postoperative first-day radiography measurements showed that reduction was good in 46 patients $(82.1 \%)$ and the reduction was acceptable in 10 patients
(I7.9\%) in group $\mathrm{I}$. In the second group, the reduction was good in $4 \mathrm{I}$ patients $(78.8 \%)$ while reduction was acceptable in II patients (18\%). No statistically significant difference was observed between the two groups (Table 2).

\section{Parker Index}

In the first group, Parker index examination showed that the lag screw was placed in low or center position in all cases in AP radiography while the lag screw was not located in a central position in seven patients (13.7\%) in lateral radiographs. On the other hand, in the second group, the lag screw was not placed at the low or center position in one patient $(2 \%)$ in AP radiography, while it was not in the center position in four ( $8 \%$ ) patients in lateral radiography. There was no statistically significant difference between the two groups when considering Parker index examination (Table 2).

\section{TAD}

In postoperative first radiographs, the mean TAD measurement in the group I was $19.23 \pm 6.5 \mathrm{~mm}$ (ranging from 4.4 to $36.8 \mathrm{~mm}$ ), and TAD was over $25 \mathrm{~mm}$ in five patients. The mean TAD of these five patients was $31.9 \pm 2.7(28.4-36.8)$ $\mathrm{mm}$. In the second group, the mean TAD was $21.8 \pm 7.7 \mathrm{~mm}$ (ranging from 10.2 to $52 \mathrm{~mm}$ ), and TAD distance was higher than $25 \mathrm{~mm}$ in 12 patients. The mean TAD measurements of these 12 patients were $33.2 \pm 8.8(25-52) \mathrm{mm}$. Concerning TAD measurements, the number of patients with TAD measurements above $25 \mathrm{~mm}$ in group 2 was higher than that of group I $(p<0.05)($ Table 3$)$.

Table I. Comparison of groups concerning age, sex, fracture classification and fracture healing time

\begin{tabular}{lcccc}
\hline Groups & Age (years) & Gender (F/M) & Fracture classification A0/0TA & Fracture healing (weeks) \\
\hline Group I (TDFN) $n=56$ & $74.4 \pm 7.7(65-90)$ & $38 / 18$ & $A 2=38(67.9 \%)$ & $13.28 \pm 1.3(\mathrm{II}-16)$ \\
Group 2 (IT) $n=52$ & $73.6 \pm 6.2(65-89)$ & $36 / 16$ & $\mathrm{~A} 3=18(32.1 \%)$ & $13.14 \pm 1.37(\mathrm{II}-16)$ \\
$\mathrm{P}=$ & & $\mathrm{A} 2=36(69.2 \%)$ & 0.608 \\
\hline
\end{tabular}

F: Female; M: Male; AO/OTA: Arbeitsgemeinschaft für Osteosynthesefragen/Orthopedic Trauma Association; TDFN: Talon Distal Fix Nail/Lag Screw; IT: Intertan.

Table 2. Comparison of groups concerning reduction quality and Parker index on the first day postoperative radiograph

\begin{tabular}{lcccc}
\hline Groups & \multicolumn{2}{c}{ Reduction Quality } & \multicolumn{2}{c}{ Parker Index (Nonacceptable) } \\
\cline { 2 - 4 } & Good & Acceptable & AP X-Ray & Lateral X-Ray \\
\hline Group I (TDFN) & $46(82.1 \%)$ & $10(17.9 \%)$ & None & $7(13.7 \%)$ \\
Group 2 (IT) & $41(78.8 \%)$ & $11(21.1 \%)$ & $1(1.9 \%)$ & $4(7.6 \%)$ \\
P= & 0.454 & & 0.412 & 0.546 \\
\hline
\end{tabular}

TDFN: Talon Distal Fix Nail/Lag Screw; IT: Intertan. 


\section{Collodiaphysial Angle}

In postoperative first radiographs, the average collodiaphysial angle in the first group was 136.07 degrees (ranging from 128 to 150 degrees), while it was $135.5 \pm 5$ (128-150) and $135.5 \pm 5$ (128-150) degrees in the radiographs of 3rd and 6th months, respectively. In the second group, the average collodiaphysial angle was 135.3 (128-146) degrees in postoperative first radiographs, while $135.2 \pm 4.9$ (I27-146) degrees were found in both 3 rd and 6th months' radiographs. In the TDFN group (group I), eight (14.2\%) patients had varus collapse in the third month. Secondary surgery was required in two of the collapsed cases (partial endoprosthesis) (3.5\%). In the other six patients, mean varus collapse was $6.7 \pm 0.3(5-9)$ degrees. TAD measurements of patients requiring a secondary surgery were 30.7 and $46 \mathrm{~mm}$ on the first postoperative radiographs. In the IT group (group 2 ), the varus collapse was observed in two (3.8\%) patients, and one $(1.9 \%)$ of them was required a secondary surgery (partial endoprosthesis). In the other patient, varus collapse was $4.3^{\circ}$. TAD measurement of a patient requiring a secondary surgery was $52 \mathrm{~mm}$ on the first postoperative radiograph. The formation of varus collapse in TDFN group was statistically significant $(p<0.05)$, while the emerging of the collapse was not statistically significant in the IT group $(p=0.09)$. Concerning varus collapse, the number of patients in group I $(n=8)$ was higher than that of group $2(n=2)(p<0.05)$ (Table 4).

\section{Cut-out}

In the first group, eight patients who experienced varus collapse also experienced cut-out at the same time. Surgical treatment with partial endoprosthesis was required in two of these eight patients. The mean cut-out of the other six patients was $4.21 \pm 1.02(2-6) \mathrm{mm}$. In the second group, cutout was observed in two patients who also experienced varus collapse. In one patient, a secondary surgery with partial prosthesis was required while in the other case, the measurement of cut-out was $3.75 \mathrm{~mm}$. The number of patients who experienced cut-out was statistically significant between the groups $(p<0.05)$ (Table 4$)$.

\section{Complications due to Nail Design}

No major complications were encountered in the TDFN group during either nail application or postoperative follow-up. In this group, five patients had pain in the groin region which did not decrease the quality of daily life. In the IT group, a trochanter major fracture occurred in three patients during the surgery and a femoral shaft fracture was observed in one case two months after the surgery. In the IT group, the objective complication was observed in four patients; however, no complication was detected in the TDFN group. The number of patients who experienced nail-dependent complications was statistically significant between the groups $(p<0.05)$ (Table 4$)$.

\section{DISCUSSION}

In this single-center retrospective study, we compared the performance of two different types of nails in intertrochanteric fractures using radiological parameters. Our findings suggest that IT nail is superior to TDFN nail in maintaining continuity of radiological parameters. Although the quality of reduction, Parker index and average collodiaphysial angles in both nail groups were similar in the first postoperative radiographs, compared to IT nail, statistically significant increase in varus collapse and cut-out complication in TDFN nail in the following months suggest that IT nail design provides better maintaining in the radiological parameters. In the Intertan group, the TAD distance of 12 patients (44.4\%) were higher than $25 \mathrm{~mm}$ while 5 (18.5\%) patients had TAD distance higher than $25 \mathrm{~mm}$ in the TDFN nails. However, the cut-out rate was significantly higher in patients who underwent TDFN

Table 3. Comparison of groups concerning mean TAD and number of patients with TAD greater than 25

\begin{tabular}{lcc}
\hline Tip apex distance & Mean $(\mathbf{m m})$ & Tip apex distance $>\mathbf{2 5} \mathbf{~ m m , ~ M e a n ~}(\mathbf{m m})$ \\
\hline Group I (Talon Distal Fix Nail / Lag Screw) & $19.23 \pm 6.5(4.4-36.8)$ & $\mathrm{n}=5(8.9 \%), 31.9 \pm 2.7(28.4-36.8)$ \\
Group 2 (Intertan) & $21.8 \pm 7.7(10.2-52)$ & $\mathrm{n}=12(23 \%), 33.2 \pm 8.8(25.2-52)$ \\
$\mathrm{P}=$ & 0.289 & $\mathrm{p}<0.05$ \\
\hline
\end{tabular}

Table 4. Comparison of groups concerning the number of patients who developed cut-out, varus collapse and complications due to nail design

\begin{tabular}{lccc}
\hline & Varus Collapse, mean (degree) & Cut-out, mean (mm) & Complication due to Nail Design \\
\hline Groupl (TDFN) & $\mathrm{n}=8,6.7^{\circ} \pm 0.3^{\circ}\left(5^{\circ}-9^{\circ}\right)$ & $\mathrm{n}=8,4.21 \pm 1.02(2-6)$ & None \\
& (in six non-surgical patients) & (in non-surgical patients) & $\mathrm{n}=4$ \\
Group2 (IT) & $\mathrm{n}=2,4.3^{\circ}$ (in non-surgical patient) & $\mathrm{n}=2,3.75$ (in non-surgical patient) & $\mathrm{p}<0.05$ \\
$\mathrm{p}=$ & $\mathrm{p}<0.05$ & $\mathrm{p}<0.05$ & \\
\hline
\end{tabular}

TDFN: Talon Distal Fix Nail/Lag Screw; IT: Intertan. 
nailing. These cumulatively suggest that the Intertan nail has better design in biomechanical perspective. Despite the high cut-out rate of TDFN nailing and the superiority of Intertan nail in providing radiological parameters, the complication rate due to nail design was higher in the Intertan group. No nail-dependent complications indicate that the learning curve of the Intertan nail surgical technique is long and the rate of nail-dependent complications is higher. When considering the general comparison between the groups, we found that the union rates and times are similar and that the similar cut-out rate requiring secondary surgery. These results highlight that both nails can be used in intertrochanteric fractures.

Previous biomechanical studies have shown that proximal femoral nails provide satisfying rigid fixation in the treatment of intertrochanteric fractures. ${ }^{[12-14]}$ There have been many studies which compare the superiority of various proximal nails clinically or biomechanically. Intertan nail is one of the most commonly used implants in the surgical treatment of intertrochanteric fractures. Several studies comparing intertan nails and different design nails have been available in the literature. For example, Duramaz et al. ${ }^{[1]}$ compared the intertan nail with PFNA and Profin nails on 203 intertrochanteric fractured patients. Their results showed that each nail design has advantages and disadvantages. $^{[1]}$ They further reported that PFNA is easier than Intertan nail concerning surgical technique, and the operation time was shorter and scopy exposure was less in PFNA 2 design. ${ }^{[1]}$ Moreover, Yu et al. ${ }^{[15]}$ examined 20 studies in their meta-analysis to compare the Intertan and PFNA nails in the treatment of patients with intertrochanteric fractures. Their outcomes indicate that both nails have similar effects on the treatment of the fracture; however, especially the Intertan nail provides a more rigid fixation against pressure and rotational forces along with providing an advantage for early ambulation and exercise. Based on their findings, they recommend the use of Intertan nail in the treatment of intertrochanteric fractures because of its low complication rate and more rigid fixation. ${ }^{[15]}$

There is also one study available comparing Intertan and PFNA concerning radiological parameters. In the study, Kochai et al. ${ }^{\left[{ }^{\prime \prime}\right]}$ compared Intertan and PFNA nails on 63 females in terms of existence varus collapse and whether they prevent shortening of the femoral neck. ${ }^{\left[{ }^{I I}\right]}$ They concluded that the Intertan nail is superior in preventing varus collapse. ${ }^{\left[{ }^{\prime I}\right]}$ To our knowledge, there is also a single study on TDFN nail. In the study conducted by Zehir et al., ${ }^{[16]}$ they compared Intertan, PFNA and TDFN on 276 patients with unstable intertrochanteric fractures concerning the fracture union time and Harris hip score. ${ }^{[16]}$ They have reported that TDFN has less complications and shorter operation time compared to PFNA, while TDFN has also a short operative time than that of Intertan has. They have emphasized that TDFN is superior to these two nails (i.e., Intertan and PFNA) in the treatment of intertrochanteric fractures. ${ }^{[16]}$ To our knowledge, the current study is the first study comparing TDFN and Intertan nail concerning radiological parameters. Our cumulative findings herein suggest that Intertan nail is superior in preventing varus collapse and cut-out complications. Moreover, thanks to its rigid fixation, the Intertan nail is superior to TDFN nail in providing the maintaining of the optimal radiological parameters. Besides this biomechanical superiority, it is important to note that it has also a higher complication rate compared to the TDFN.

TAD was first described by Baumgaertner et al. ${ }^{[10]}$ who stated that being TAD value below $25 \mathrm{~mm}$ reduces the possibility of the cut-out. Later on, TAD distance has been used as an important parameter in the prevention of cut-out complications. For instance, Caruso et al. ${ }^{[17]}$ conducted a clinical study on 57I patients and reported that TAD value below 30 $\mathrm{mm}$ is effective in preventing the complication. They further stated that TAD is an important parameter in the prediction of implant failure. ${ }^{[17]}$ In another study, Fujii et al. ${ }^{[18]}$ evaluated six factors for predicting the cut-out risk and suggested that TAD distance is the most important parameter in estimating the possibility of cut-out. Accordingly, we also examined TAD as one of the radiological parameters. When comparing the two groups, we found that TAD distance was over $25 \mathrm{~mm}$ in five patients of the TDFN group and in 12 patients of the IT group. However, the cut-out rate was significantly higher in the TDFN group. This indicates that the IT nail provides a more rigid fixation, thereby being biomechanically superior though the need for secondary surgery due to cut-out and implant failure is similar in both groups.

This work is also not without limitations. The limitations of this current study include being a retrospective design, no comparison of body mass index and no osteodensitometer results reported, and only the use of digital X-ray graphs when evaluating the position of the lag screw.

\section{Conclusion}

Our results suggest that Intertan nail provides a more rigid fixation for intertrochanteric fracture, and is superior to TDFN nail in preventing varus collapse and the cut-out complications where the implant design is also closely related to preventing its formation. The disadvantage of IT nail is, on the other hand, that implant-dependent complications are more common than TDFN.

\section{Acknowledgment}

Thanks to Aykut Akyılmaz for her assistance to the article by drawing Figure I.

Ethics Committee Approval: This study was approved by the University Ethics Committee for Clinical Research Trials (2018/04; 14. 19.04.2018) and was conducted in accordance with the principles in the Declaration of Helsinki.

Peer-review: Internally peer-reviewed.

Authorship Contributions: Concept: G.B.S.; Design: G.B.S., B.K.; Supervision: G.B.S., M.C.C.; Resource: G.B.S., B.K.; Materials: G.B.S., M.C.C., B.K.; Data: G.B.S., M.C.C., B.K.; Analysis: G.B.S.; Literature search: G.B.S., B.K.; Writing: 
G.B.S.; Critical revision: G.B.S., M.C.C.

Conflict of Interest: None declared.

Financial Disclosure: The authors declared that this study has received no financial support.

\section{REFERENCES}

1. Duramaz A, İlter MH. The impact of proximal femoral nail type on clinical and radiological outcomes in the treatment of intertrochanteric femur fractures: A comparative study. Eur J Orthop Surg Traumatol 2019;29:1441-9. [CrossRef]

2. Lang NW, Breuer R, Beiglboeck H, Munteanu A, Hajdu S, Windhager $\mathrm{R}$, et al. Migration of the lag screw after intramedullary treatment of $\mathrm{AO} /$ OTA 31. A2.1-3 perthrocantheric fractures does not result in higher incidence of cut-outs, regardless of which implant was used: A comparison of gamma nail with and without U-blade (RC) lag screw and proximal femur nail antirotation (PFNA). J Clin Med 2019;8:615-26. [CrossRef]

3. de Landevoisin ES, Bertani A, candoni P, Charpail C, Demortiere E. Proximal femoral nail antirotation (PFN-ATM) fixation of extra-capsular proximal femoral fractures in the elderly: Retrospective study in 102 patients. Orthop Traumatol Surg Res 2012;98:288-95. [CrossRef]

4. Talmaç MA, Görgel MA, Armağan R, Sönmez MM, Ozdemir HM. Examining implant superiority in the treatment of simple pertrochantericfractures of the proximal femur in elderly patients. Ulus Travma Acil Cerrahi Derg 2019;25:410-6. [CrossRef]

5. Uzer G, Elmadağ NM, Yıldız F, Bilsel K, Erden T, Toprak H. Comparison of two types of proximal femoral nails in the treatment of intertrochanteric femur fractures. Ulus Travma Acil Cerrahi Derg 2015;21:385-91.

6. Geller JA, Saifi C, Morrison TA. Tip-apex distance of intramedullary devices as a predictor of cut-out failure in the treatment of peritrochanteric elderly hip fractures. Int Orthop 2010;34:719-22. [CrossRef]

7. Aicale R, Maffulli $H$. Greater rate of cephalic screw mobilisation following proximal femoral nailing in hip fractures with a tip-adex distance (TAD) and calcar referenced TAD greater than $25 \mathrm{~mm}$. J Orthop Surg
Res 2018;13:106. [CrossRef]

8. Parker M. Cutting-out of the dynamic hip screw related to its position. J Bone Joint Surg Br 1992;74:625. [CrossRef]

9. Parmar V, Kumar S, Aster A, Harper WH. Review of methods to quantify lag screw placement in hip fracture fixation. Acta Orthop Belg 2005;3:260-3.

10. Baumgaertner MR, Curtin SL, Lindskog DM, Keggi JM. The value of the tip-apex distance in predicting failure of fixation of peritrochanteric fractures of the hip. J Bone Joint Surg Am 1995;77:1058-64. [CrossRef]

11. Kochai A, Uysal M, Ozalay M, Cinar BM, Battal V, Avcı MC. Comparision of PFN and intertan nail for unstable intertrochanteric femoral fracture in mobile patients. Int J Clin Med 2019;12:5468-74.

12. Schipper IB, Bresina S, Wahl D, Linke B, van Vught AB, Schneider E. Biomechanical evaluation of the proximal femoral nail. Clin Orthop Relat Res 2002;405:277-86. [CrossRef]

13. Mahomed N, Harrington I, Kerllam J, maistrelli, G, Hearn T, Vroemen J. Biomechanical analysis of the gamma nail and sliding hip screw. Clin Orthop Relat Res 1994;304:280-8. [CrossRef]

14. Curtis MJ, Jinnah RH, Wilson V, Cunningham BW. Proximal femoral fractures: A biomechanical study to compare intramedullary and extramedullary fixation. Injury 1994;??? :280-8. [CrossRef]

15. Yu C, Jiang LH, Cai DW, Wu J, Qin J. PFNA and InterTAN intramedullary nailing in elderly patients with femoral intertrochanteric fractures: A meta analysis. Zhongguo Gu Shang 2019;32:120-9.

16. Zehir S, Sahin MD, Zehır R. Comparison of clinical outcomes with three different intramedullary nailing devices in the treatment of unstable trochanteric frectures. Ulus Travma acil Cerrahi Derg 2015;21:469-76.

17. Caruso G, Bonomo M, Valpiani G, Salvatori G, Gildone A, Lorusso V, et al. A six-year retrospective analysis of cut-out risk predictors in cephalomedullary nailing for pertrochanteric fractures: Can the tip-apex distance (TAD) still be considered the best parameter? Bone Joint Res 2017;6:481-8.

18. Fujii T, Nakayama S, Hara M, Koizumi W, Itabashi T, Saito M. Tip-apex distance is most important of six predictors of screw cutout after internal fixation of intertrochanteric fractures in women. JB JS Open Access 2017;2:e0022. [CrossRef]

\section{ORIJINAL ÇALIŞMA - ÖZET}

\section{İnstabil intertrokanterik kırıklarda iki farklı proksimal femoral çivinin radyolojik parametreler açısından karşılaştırılması}

\section{Dr. Gökhan Bülent Sever, ${ }^{1}$ Dr. Mehmet Cenk Cankuş, ${ }^{1}$ Dr. Burçin Kars $\mid{ }^{2}$}

'Sanko Üniversitesi Tıp Fakültesi Uygulama ve Araştırma Hastanesi, Ortopedi ve Travmatoloji Kliniği, Gaziantep ${ }^{2}$ Gaziantep Üniversitesi Tıp Fakültesi, Ortopedi ve Travmatoloji Anabilim Dalı, Gaziantep

AMAÇ: Bu çalışmanın amacı instabil intertrokanterik kırı̆ı olan 65 yaş üzeri mobil hastalarda kapalı redüksiyon ve proksimal femoral çivileme tedavisinde kullanılan iki farklı çiviyi radyolojik parametreler açısından karşılaşırımaktır.

GEREÇ VE YÖNTEM: Haziran 2013 ve Ağustos 2018 tarihleri arasında tek merkezde intertrokanterik kırık tanısı ile kapalı redüksiyon ve internal fiksasyon uygulanan ameliyat öncesi mobil olan 65 yaşı üzerinde 108 olgu çalısmaya dahil edildi. Olgular kullanılan proksimal femoral çiviye göre 2 gruba ayrıldı (Intertan (IT) ve Talon Distal Fix Nail/Lag Screw (TDFN)). Gruplar yaş, cinsiyet, komplikasyon oranları ve radyolojik parametrelerine (redüksiyon kalitesi, tip apex distance (TAD), Parker indeksi, kaynama zamanı, cut out oranı, varus kollapsı) göre karşılaştırıldı.

BULGULAR: Gruplar arasında yaş, cinsiyet, kaynama zamanı ve postoperatif ilk grafide ölçülen redüksiyon kalitesi, Parker indeksi, kollodiafizyal açı açısından fark yoktu. Postoperatif ilk grafide IT grubunda I2, TDFN grubunda 5 olguda TAD ölçümü 25 mm üzerindeydi. TAD ölçümünün yükssek olduğu hasta sayısının istatistiksel olarak IT grubunda fazla olmasına rağmen varus kollapsı ve cut out komplikasyonlarının TDFN çivisinde istatistiksel olarak fazla görüldüğü gözlendi. IT kullanılan grupta 4 olguda çivi bağımlı komplikasyona rastlandı. (3 olguda trokanter majör kırı̆̆ı, I olguda distal vida yerinden femur kırığı) TDFN grubunda çivi dizaynına bağlı komplikasyona rastlanmadı.

TARTıŞMA: Varus kollapsı ve cut out komplikasyonlarını önlemekte ve radyolojik parametrelerin kırık kaynamasına kadar devamlılı̆ını sağlamakta intertan çivisinin odi çivisine göre daha üstün olduğu saptandı. Bunun yanında intertan çivisi kullanılan hastalarda komplikasyon oranının daha yüksek olması bu çivinin handikapı olarak görüldü.

Anahtar sözcükler: Femur intertrokanterik kırı̆̆ı; karşılaştırma; proksimal femoral çivi; radyolojik parametreler.

Ulus Travma Acil Cerrahi Derg 2021;27(3):344-350 doi: 10.14744/tjtes.2020.41343 